\title{
The estimated burden of fungal disease in South Africa
}

\author{
I S Schwartz, ${ }^{1} \mathrm{MD}, \mathrm{PhD}$, FRCPC; T H Boyles, ${ }^{2} \mathrm{MB}$ ChB, Cert ID (SA); C R Kenyon, ${ }^{3,4}$ MB ChB, FCP (SA), Cert ID (SA), PhD; \\ J C Hoving, ${ }^{5} \mathrm{MSc}$ (Med), PhD; G D Brown, ${ }^{5,6} \mathrm{PhD}$; D W Denning, ${ }^{7,8} \mathrm{MB}$ BS, FRCP, FRCPath, FMedSci \\ ${ }^{1}$ Division of Infectious Diseases, Department of Medicine, Faculty of Medicine and Dentistry, University of Alberta, Edmonton, Canada \\ ${ }^{2}$ Wits Reproductive Health and HIV Institute, University of the Witwatersrand, Johannesburg, South Africa \\ ${ }^{3}$ University of Cape Town, South Africa \\ ${ }^{4}$ Institute of Tropical Medicine, Antwerp, Belgium \\ ${ }^{5}$ AFGrica Unit, Institute of Infectious Disease and Molecular Medicine, University of Cape Town, South Africa \\ ${ }^{6}$ Medical Research Council Centre for Medical Mycology at the University of Aberdeen, Aberdeen Fungal Group, Institute of Medical Sciences, \\ University of Aberdeen, UK \\ ${ }^{7}$ University of Manchester and National Aspergillosis Centre, Wythenshawe Hospital, Manchester University Hospital Foundation Trust, \\ Manchester Academic Health Science Centre, UK \\ ${ }^{8}$ Global Action Fund for Fungal Infections, Geneva, Switzerland
}

Corresponding author: I S Schwartz (ilan@ualberta.ca)

Background. With a population of 56.5 million, over 7 million persons living with HIV, one of the world's highest rates of tuberculosis (TB) and a large proportion of the population living in poverty, South Africa (SA)'s fungal disease burden is probably substantial and broad in scope. Objectives. To estimate the burden of fungal disease in SA.

Methods. Using total and at-risk populations and national, regional and occasionally global data, we estimated the incidence and prevalence of the majority of fungal diseases in SA.

Results. Estimates for the annual incidence of HIV-related life-threatening fungal disease include cryptococcal meningitis (8 357 cases), Pneumocystis pneumonia (4 452 cases) and endemic mycoses (emergomycosis, histoplasmosis and blastomycosis, with 100, 60 and 10 cases per year, respectively). We estimate 3885 cases of invasive aspergillosis annually. The annual burden of candidaemia and Candida peritonitis is estimated at 5421 and 1901 cases, respectively. The epidemic of pulmonary TB has probably driven up the prevalence of chronic pulmonary aspergillosis to 99351 (175.8/100 000), perhaps the highest in the world. Fungal asthma probably affects $>100000$ adults. Mucosal candidiasis is common, with an annual prevalence estimated at 828666 and 135289 oral and oesophageal cases, respectively, complicating HIV infection alone (estimates in other conditions not made), and over a million women are estimated to be affected by recurrent vulvovaginal candidiasis each year. Tinea capitis in children is common and conservatively estimated at $>1000000$ cases. The inoculation mycoses sporotrichosis, chromoblastomycosis and eumycetoma occur occasionally (with 40,40 and 10 cases estimated, respectively). Overall, we estimate that over 3.2 million South Africans are afflicted by a fungal disease each year ( $7.1 \%$ of the population). Conclusions. Significant numbers of South Africans are estimated to be affected each year by fungal infections, driven primarily by the syndemics of HIV, TB and poverty. These estimates emphasise the need for better epidemiological data, and for improving the diagnosis and management of these diseases.

S Afr Med J 2019;109(11):885-892. https://doi.org/10.7196/SAMJ.2019.v109i11.13718

Fungal infections are common and diverse in South Africa (SA), driven in large part by the syndemics of HIV, tuberculosis (TB) and poverty. SA has the dubious distinctions of having the largest HIV epidemic, ${ }^{[1]}$ one of the highest incidences of $\mathrm{TB}^{[2]}$ and - by some measures - the most socioeconomic inequity ${ }^{[3]}$ in the world. Each of these conditions on its own or in combination can predispose individuals to fungal disease, but to our knowledge, the burden of such infections in SA has not previously been estimated.

\section{Objectives}

To estimate the prevalence and incidence of fungal infections in SA, excluding cutaneous infections with the sole exception of tinea capitis because of its severity in a significant minority of children.

\section{Methods}

The burden of fungal disease in SA was estimated using the methodologies of LIFE-worldwide.org. ${ }^{[4]}$ Starting estimates for fungal disease or for conditions complicated by fungal disease were obtained by review of the English language literature. National or local data were preferred, but where these were unavailable, data were extrapolated from other sources in order of decreasing preference: from other countries in southern Africa, elsewhere in Africa, nonAfrican middle-income countries, and non-African non-middleincome countries. We also calculated $25 \%$ sensitivity bounds $(25 \%$ lower and $25 \%$ higher than the base estimate) to reflect uncertainty in these estimates.

Prevalence data for conditions that may become complicated by fungal infections were obtained from national surveys, registries or published estimates (Table 1). SA population estimates and HIVrelated deaths were obtained from Statistics South Africa. ${ }^{[5]}$ The number of people living with HIV/AIDS (PLWH), the proportion of adult ( $\geq 15$ years) PLWH with CD4+ counts $<200$ cells $/ \mu \mathrm{L}$, and antiretroviral therapy (ART) coverage were obtained from the Thembisa model, version 3.2. ${ }^{[6]}$ Among adult PLWH with CD4+ counts $<200$ cells $/ \mu \mathrm{L}$, we assumed that half had counts $<100$ cells/ $\mu \mathrm{L}$ based on Carmona et al. ${ }^{[7]}$ who reported that of 654868 PLWH 
Table 1. Population characteristics and underlying comorbidities in South Africans

\begin{tabular}{|c|c|c|}
\hline Population characteristic & $n$ & Source \\
\hline Total population & 56521947 & Statistics South Africa ${ }^{[5]}$ \\
\hline Women aged 15 - 54 years & 16708323 & Statistics South Africa ${ }^{[5]}$ \\
\hline Children $(<15$ years $)$ & 16724831 & Statistics South Africa ${ }^{[5]}$ \\
\hline Persons living with HIV & 7046301 & Thembisa model ${ }^{[6]}$ \\
\hline Adults living with HIV + CD4+ $<200$ cells $/ \mu \mathrm{L}$ & 676445 & Thembisa model ${ }^{[6]}$ \\
\hline Adults livings with $\mathrm{HIV}+\mathrm{CD} 4+<350$ cells $/ \mu \mathrm{L}$ & 2012674 & Thembisa model ${ }^{[6]}$ \\
\hline Persons living with HIV on ART & 3723118 & Thembisa model ${ }^{[6]}$ \\
\hline Children living with HIV & 329430 & Thembisa model ${ }^{[6]}$ \\
\hline Children living with HIV on ART & 181372 & Thembisa model ${ }^{[6]}$ \\
\hline AIDS deaths & 126755 & Statistics South Africa ${ }^{[5]}$ \\
\hline Annual cases of TB & 438000 & World Health Organization ${ }^{[2]}$ \\
\hline Annual cases of pulmonary TB & 394000 & World Health Organization ${ }^{[2] *}$ \\
\hline Adults with asthma & 2477539 & World Health Survey ${ }^{[10]}$ \\
\hline Adults with COPD & 2249688 & Global Burden of Disease $2015^{[9]}$ \\
\hline Renal transplants per year & 249 & Organ Donor Foundation ${ }^{[11]}$ \\
\hline Lung transplants per year & 14 & Organ Donor Foundation ${ }^{[11]}$ \\
\hline Heart transplants per year & 25 & Organ Donor Foundation ${ }^{[11]}$ \\
\hline Liver transplants per year & 35 & Organ Donor Foundation ${ }^{[11]}$ \\
\hline Allogeneic stem cell transplants per year & 107 & EBMT survey $y^{[12]}$ \\
\hline Persons with lung cancer & 7793 & Global Burden of Disease $2015^{[9]}$ \\
\hline Persons with acute myelogenous leukaemia & 518 & Global Burden of Disease $2015^{[9]}$ \\
\hline Persons on peritoneal dialysis & 1668 & South African Renal Registry ${ }^{[13]}$ \\
\hline ICU beds & 4719 & Naidoo et al., 2013 $3^{[38]}$ \\
\hline
\end{tabular}

who entered care in SA in 2016, 32.9\% had CD4+ counts $<200$ cells/ $\mu \mathrm{L}$ and $16.8 \%$ had counts $<100$ cells $/ \mu \mathrm{L}$, and Coetzee et al., ${ }^{\left[{ }^{8]}\right.}$ who reported that among PLWH who had a CD4+ measurement in $2014-2015,20.56 \%$ had counts $<200$ cells $/ \mu \mathrm{L}$ and $9.69 \%$ had counts $<100$ cells $/ \mu \mathrm{L}{ }^{[8]}$ National TB data were obtained from the World Health Organization (WHO) ${ }^{[2]}$ National prevalence data for lung cancer and chronic obstructive pulmonary disease (COPD) and incidence data for acute myeloid leukemia (AML) were obtained from the 2016 Global Burden of Disease study. ${ }^{[9]}$ The prevalence of asthma in adults was assumed to be $6.09 \%$, based on the World Health Survey. ${ }^{[10]}$ Transplantation volume was obtained from the Organ Donor Foundation. ${ }^{[1]}$ The number of autologous stem cell transplants in 2014 was obtained from Passweg et al. ${ }^{[12]}$ and the number of endstage kidney disease patients receiving peritoneal dialysis (PD) in 2015 was reported by the South African Renal Registry. ${ }^{[13]}$

Assumptions on which we predicated estimates of each mycosis are detailed in Table 2. The burden of cryptococcal meningitis was obtained using national laboratory surveillance data from the National Health Laboratory Service's Group for Enteric, Respiratory and Meningeal Diseases Surveillance in South Africa (GERMS-SA), ${ }^{[14]}$ with a correction of $20 \%$ to account for the possibility of undiagnosed cases. We estimated the burden of Pneumocystis pneumonia (PCP) in adults and children separately. For adults, we assumed that $10 \%$ of PLWH who had CD4+ counts $<100$ cells/ $\mu \mathrm{L}$ were hospitalised each year ${ }^{[15]}$ and based on the observation from SA that $\sim 10 \%$ of PLWH admitted to hospital with WHO danger signs and cough were diagnosed with $\mathrm{PCP}^{[16]}$ we assumed that $5 \%$ of hospitalisations among PLWH who had CD4+ counts $<100$ cells $/ \mu \mathrm{L}$ were caused by PCP. We assumed that $21 \%$ of childhood pneumonia deaths were attributable to PCP, based on data from Botswana; ${ }^{[17]}$ additionally, we assumed that childhood PCP carried a $40 \%$ mortality rate. ${ }^{[18,19]}$ Invasive aspergillosis (IA) was assumed to occur as a complication of other disease states or immunocompromising conditions. IA was assumed to complicate $10 \%$ of cases of AML, and an equivalent number of cases among all other non-AML haematological malignancies. ${ }^{[20]}$ IA was assumed to complicate $10 \%$ of allogeneic stem cell transplants, $0.5 \%, 4 \%, 6 \%$, and $4 \%$ of kidney, lung, heart and liver transplants, respectively, based on North American data, ${ }^{[21]}$ and $2.6 \%$ of cases of lung cancer, based on Chinese data. ${ }^{[22]}$ IA was additionally assumed to complicate $1.3 \%$ of severe acute exacerbations of COPD requiring hospitalisation (which was assumed to affect the most severe decile of patients with this condition). ${ }^{[23]}$ Although IA was implicated in $4 \%$ of HIV-related deaths in a study from Italy, ${ }^{[24]}$ similar findings have not been reported in autopsy studies from SA. ${ }^{[25-29]}$ We therefore conservatively estimated that $0.5 \%$ of HIV-related deaths were caused by IA. Mucormycosis was assumed to affect 2 per million of the population based on data from Europe. ${ }^{[30,31]}$

Chronic pulmonary aspergillosis (CPA) was assumed to complicate pulmonary TB with and without cavitary lesions in $22 \%$ and $2 \%$ of cases, respectively. ${ }^{[2,33]}$ We assumed that $22 \%$ of cases of pulmonary $\mathrm{TB}$ cavitate. We also assumed that pulmonary $\mathrm{TB}$ is the underlying diagnosis in $80 \%$ of all CPA cases. Allergic bronchopulmonary aspergillosis (ABPA) was assumed to occur in $2.5 \%$ of adult asthmatics, based on SA and international data. ${ }^{[3,35]}$ Severe asthma with fungal sensitisation (SAFS) was estimated to occur in $30 \%$ of the most severe decile of asthmatics. ${ }^{[36]}$ Although ABPA is also known to complicate cystic fibrosis, estimates of the prevalence of this disease in SA were unavailable.

The burden of candidaemia was assumed to occur in intensive care unit (ICU) and non-ICU inpatient settings at a ratio of $2: 1 .^{[37]}$ We determined the number of ICU beds from a national survey from 2008 to $2009^{[38]}$ and assumed $90 \%$ bed utilisation. The 
Table 2. Assumptions on which estimates of mycoses are predicated ${ }^{\star}$

\begin{tabular}{|c|c|c|c|}
\hline Mycosis & Assumptions & $\begin{array}{l}\text { Geographical origin of data } \\
\text { informing assumptions }{ }^{\dagger}\end{array}$ & Reference \\
\hline Cryptococcal meningitis & $\begin{array}{l}\text { Reported surveillance data from NICD, plus } 20 \% \\
\text { correction for missed diagnoses }\end{array}$ & National & GERMS-SA $2017^{[14]}$ \\
\hline Pneumocystis pneumonia & $\begin{array}{l}\text { For adults, assumed to cause } 5 \% \text { of all } \\
\text { hospitalisations among PLWH with CD } 4+ \\
<100 \text { cells/ } \mu \mathrm{L} \text { ( } 10 \% \text { of whom were assumed to } \\
\text { be hospitalised each year) } \\
\text { In children, PCP assumed to be attributable for } 21 \% \\
\text { of childhood pneumonia deaths and we assumed } \\
\text { that } 40 \% \text { childhood PCP cases were fatal }\end{array}$ & National + regional & $\begin{array}{l}\text { Maartens et al., } 2018^{[16]} \\
\text { Meyer-Rath et al., 2013 } \\
\text { Ansari et al., 2003 } \\
\text { Zar et al., 2001 } \\
\text { Morrow et al., 2014 }\end{array}$ \\
\hline Invasive aspergillosis & $\begin{array}{l}\text { Complicates } 10 \% \text { of cases of AML per year and an } \\
\text { equivalent number among all other haematological } \\
\text { malignancies; complicates } 10 \% \text { of allogeneic } \\
\text { HSCT, } 0.5 \% \text { of kidney SOT, } 4 \% \text { of lung SOT, } 6 \% \\
\text { of heart SOT, } 4 \% \text { of liver SOT, and } 2.6 \% \text { of cases } \\
\text { of lung cancer; } 0.5 \% \text { of patients dying of HIV; and } \\
1.3 \% \text { of the worst } 10 \% \text { of COPD patients (usually } \\
\text { hospitalised) }\end{array}$ & International & 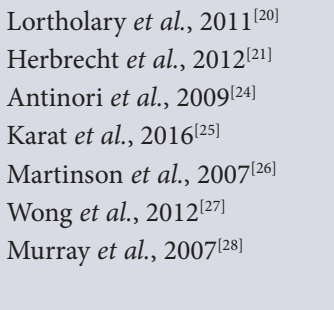 \\
\hline CPA & $\begin{array}{l}\text { Complicates } 22 \% \text { of pulmonary TB cases with } \\
\text { cavitation and } 2 \% \text { of pulmonary TB cases without } \\
\text { cavitation; cavitary disease assumed to comprise } \\
22 \% \text { of cases of pulmonary TB. Pulmonary TB } \\
\text { assumed to underlie } 80 \% \text { of cases of CPA }\end{array}$ & National + international & $\begin{array}{l}\text { Denning et al., } 2011^{[32]} \\
\text { Sonnenberg et al., } 2000^{[33]}\end{array}$ \\
\hline ABPA & Assumed to affect $2.5 \%$ of asthmatic adults & National + international & $\begin{array}{l}\text { Benatar et al., } 1980^{[34]} \\
\text { Denning et al., } 2013^{[35]}\end{array}$ \\
\hline SAFS & $\begin{array}{l}\text { Assumed to affect } 30 \% \text { of the most severe decile of } \\
\text { asthmatic adults }\end{array}$ & International & Denning et al., $2014^{[36]}$ \\
\hline Candidaemia & $\begin{array}{l}\text { Rate of ICU-associated candidaemia in adults in } \\
\text { public hospital ICUs is assumed to be equivalent to } \\
\text { that reported at Chris Hani Baragwanath Hospital, } \\
\text { and assumed to be double that of private hospital } \\
\text { ICUs. } 90 \% \text { of ICU beds assumed to be occupied. } \\
\text { Ratio of candidaemic episodes in adults receiving } \\
\text { care in ICU to non-ICU beds assumed to be } 2: 1\end{array}$ & National + international & $\begin{array}{l}\text { Kreusch and Karstaedt, } \\
2013^{[39]} \\
\text { Tshukutsoane and Scribante, } \\
2008^{[40]} \\
\text { Govender et al., } 2016^{[37]}\end{array}$ \\
\hline Candida peritonitis & $\begin{array}{l}\text { Post-surgical Candida peritonitis is half as common } \\
\text { as ICU-related candidemia; PD patients assumed to } \\
\text { have } 1.7 \text { episodes of peritonitis per year, with } 3.8 \% \\
\text { due to Candida }\end{array}$ & National + international & $\begin{array}{l}\text { Montravers et al., } 2011^{[41]} \\
\text { Okpechi et al., 2012 } \\
\text { Isla et al., 2014 }\end{array}$ \\
\hline Oral candidiasis & $\begin{array}{l}\text { Among adults, } 38 \% \text { of PLWH with CD } 4+ \\
<350 \text { cells/ } \mu \mathrm{L} \text {; for children living with HIV, oral } \\
\text { candidiasis assumed to affect } 37 \% \text { not on ART } \\
\text { and } 5 \% \text { on ART }\end{array}$ & National + regional & $\begin{array}{l}\text { Arendorf et al., 1998 } \\
\text { Nanteza et al., 2014 } \\
\text { Meless et al., 2014 } \\
\text { Rwenyonyi et al., 2011 } \\
\text { Rwe }\end{array}$ \\
\hline Oesophageal candidiasis & $20 \%$ of PLWH with CD $4<200$ cells $/ \mu \mathrm{L}$ & International & Smith and Orholm, $1990^{[49]}$ \\
\hline $\begin{array}{l}\text { Recurrent vulvovaginal } \\
\text { candidiasis }\end{array}$ & $\sim 6 \%$ of women between 15 and 54 years of age & International & $\begin{array}{l}\text { Foxman et al., 2013 } \\
\text { Denning et al., 2018 }\end{array}$ \\
\hline Tinea capitis & $6 \%$ of children $<15$ years of age & National + regional & $\begin{array}{l}\text { Nweze and Eke, } 2017^{[54]} \\
\text { Young, } 1976^{[55]}\end{array}$ \\
\hline Mucormycosis & 2 cases per million population & International & Bitar et al., 2009 $9^{[31]}$ \\
\hline \multicolumn{4}{|c|}{ 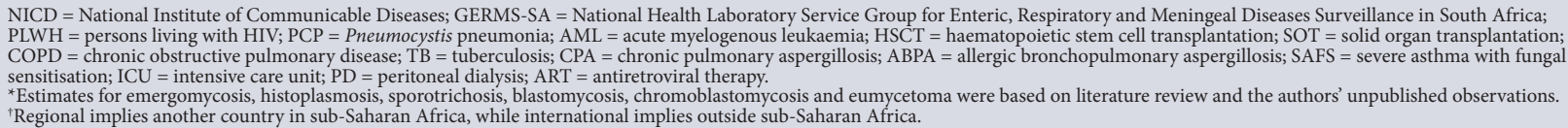 } \\
\hline
\end{tabular}

incidence of ICU-associated candidaemia in public hospital ICUs was extrapolated from cross-sectional data from Soweto. ${ }^{[39,40]}$ We assumed that the rate of candidaemia in private hospital ICUs was half that of public hospital ICUs, based on the assumption of lower general acuity and complexity of private hospital ICU patients that follows from greater accessibility ( $75 \%$ of ICU beds were in the private sector, which provides care for $\sim 15 \%$ of the population ${ }^{[38]}$ ). We assumed that post-surgical Candida peritonitis (intra-abdominal candidiasis) was 
half as frequent as ICU-associated candidaemia, as it was in France. ${ }^{[41]}$ In addition, the incidence of Candida peritonitis associated with PD was estimated based on the number of PD patients and according to reports of PD-associated peritonitis from Cape Town and Limpopo Province. ${ }^{[42,43]}$ Oral candidiasis was assumed to affect $38 \%$ of adult PLWH who had CD4+ counts $<350$ cells $/ \mu \mathrm{L}$; this estimate was based on a large SA study in the pre-ART era that reported oral candidiasis among $38 \%$ of HIV-infected patients, ${ }^{[4]]}$ in addition to a study from Uganda that suggested that this opportunistic infection is significantly more likely below this $\mathrm{CD} 4+$ threshold. ${ }^{[45]}$ Oral candidiasis was assumed to affect $5 \%$ of children living with HIV on $\mathrm{ART}^{[46]}$ and $37 \%$ of children living with HIV not taking ART, ${ }^{[47,48]}$ based on data from elsewhere in sub-Saharan Africa. Oesophageal candidiasis was assumed to affect $20 \%$ of adult PLWH who had CD4+ counts $<200$ cells $/ \mu \mathrm{L}$, based on a study from Denmark of patients with AIDS; ${ }^{[49]}$ estimates were not attempted for this disease among children. Although vulvovaginal candidiasis occurs more frequently in HIV-infected women than in HIV-uninfected women, ${ }^{[50]}$ most SA studies are cross-sectional and not longitudinal, and therefore do not inform the incidence of recurrence. ${ }^{[50,51]}$ Based on international data, ${ }^{[52,53]}$ we conservatively assumed that recurrent vulvovaginal candidiasis - defined as $\geq 4$ episodes per year - had a prevalence of $6 \%$ among females aged 15 - 54 years; this risk was not adjusted for HIV status.

Based on a review of SA and southern African literature, we estimated the prevalence of tinea capitis among children aged $<15$ years to be $6 \% \cdot{ }^{[54,55]}$ Among these, at least $2 \%$ and perhaps as many as $14 \%$ of cases are complicated, with inflammatory tinea capitis or kerion. ${ }^{[56,57]}$ The incidences of endemic and inoculation mycoses were estimated based on the authors' experience and the published literature. ${ }^{[58-63]}$ We could find no data on fungal keratitis.

\section{Results}

In total, we estimated the occurrence of 3220014 cases of fungal infections each year (Table 3), with a sensitivity bounds of 2415010 4025 017. We estimated 8357 cases of HIV-associated cryptococcal meningitis each year $(14.8 / 100000)$. This disease is rare in children: $3 \%$ of cases audited by GERMS-SA were diagnosed in patients aged $<15$ years. ${ }^{[14]}$ We estimated 1691 cases of PCP per year in adults $(4.3 / 100000)$ and 2761 cases in children (16.5/100 000), for a total of 4452 cases per year $(7.9 / 100000)$.

We estimated a total of 3885 cases of IA annually (4.7/100 000), including 3128 cases among persons with COPD or lung cancers, 576 cases among PLWH and 120 cases among persons with other malignancies or transplant recipients. There were estimated to be 394000 cases of pulmonary TB per year; ${ }^{[2]}$ it was assumed that $10 \%$ of these patients died, leaving an estimated 354600 survivors. We estimated 22694 incident cases annually and 71533 prevalent cases of CPA complicating TB (carrying an annual 15\% mortality or surgical resection rate). In total, the prevalent burden of CPA was estimated as 89416 cases. The burdens of ABPA and SAFS were estimated as 60591 and 79980 cases, respectively, although there is likely to be some duplication: some ABPA patients have severe asthma, and all are sensitised to Aspergillus fumigatus.

In 2008 - 2009, there were 4719 critical care beds in SA. ${ }^{[38]}$ Of these, $3533(75 \%)$ were in private sector hospitals that provide care for $\sim 15 \%$ of the population, ${ }^{[64]}$ and $1186(25 \%)$ were in the public sector. ${ }^{[38]}$ We assumed an occupation rate of $90 \%$ of ICU beds across both public and private hospitals. Between 2005 and 2007, there were 49 episodes of candidaemia reported in adult ICU patients at Chris Hani Baragwanath Hospital, a 2 700-bed tertiary hospital in Soweto with an 18-bed ICU, ${ }^{[39]}$ giving a rate of 1.36 episodes of candidaemia per ICU bed per year. If one extrapolates this rate to all occupied public hospital ICU beds and assumes that this rate is halved in private hospital ICUs, it can be calculated that there were 3614 episodes of candidaemia in adult ICUs. Govender et al. ${ }^{[37]}$ noted that two-thirds of episodes of candidaemia occurred in ICU patients in a passive laboratory-based surveillance programme tracking resistance to antifungal drugs in Candida species in SA (TRAC-South Africa). We would therefore expect 1807 episodes in adults outside ICUs for a total of 5421 episodes of candidaemia per year (9.6/100 000). Reliable data regarding rates of candidaemia in neonatal ICUs could not be found, although Govender et al. ${ }^{[37]}$ reported that a quarter of isolates collected in the TRAC-South Africa study were from neonates. If we assume that post-surgical Candida peritonitis is half as frequent as candidaemia in ICUs, as it was in France, then 1807 cases are anticipated. In 2015, 1668 end-stage kidney disease patients received PD across SA. ${ }^{[13]}$ In a Cape Town cohort of patients receiving PD in 2010, the incidence of peritonitis was 1.7 episodes per patient per year and $3.8 \%$ of episodes were caused by fungi. ${ }^{[42]}$ In Limpopo, the incidence of PD-related peritonitis in 2008 was 0.8 episodes per year, also with $3.8 \%$ caused by fungi. ${ }^{[43]}$ If we assume an average incidence of PD-related peritonitis of 1.3 episodes per patient per year, with $3.8 \%$ caused by Candida, then an additional 82 cases of Candida peritonitis are anticipated, for a total of 1901 incident cases of Candida peritonitis (3.4 cases/100 000). We estimated 828666 PLWH with oral candidiasis, including 764816 adults and 63850 children. Additionally, we estimated that 135289 adult PLWH had oesophageal candidiasis. An estimated 1002499 women were afflicted by recurrent vulvovaginal candidiasis each year.

Several studies have reported on tinea capitis among children in subSaharan Africa. ${ }^{[54]}$ In 1976, Young ${ }^{[5]}$ reported prevalence rates of tinea capitis of $19 \%$ and $12 \%$ among rural black children in the Northern Transvaal and Eastern Transvaal provinces of SA, respectively, with an overall prevalence of $15 \%$. Using the conservative estimate that $6 \%$ of SA children aged $<15$ years would be affected by tinea capitis, we estimated 1003490 such infections. Among these, we estimate the occurrence of at least 20000 and perhaps as many as 130000 cases of inflammatory tinea capitis or kerion, a painful and stigmatising disease that can become complicated by permanent hair loss. ${ }^{[6,57]}$

Dimorphic fungal infections are reported sporadically and are occasionally associated with outbreaks. The recent introduction of molecular typing methods for identification of dimorphic fungi has resulted in recognition of Emergomyces africanus (formerly Emmonsia sp.) as the most common dimorphic fungus implicated in human disease in SA. ${ }^{[65]}$ In a prospective study of PLWH with CD4+ counts $<100$ cells $/ \mu \mathrm{L}$ and recent-onset, widespread skin lesions (the most common clinical manifestation of disease) who were receiving care at public sector hospitals in Cape Town, 14 cases of emergomycosis were diagnosed in as many months. ${ }^{[58]}$ Among hospitals in Gauteng Province, 10 cases were diagnosed during a 14-month period in 2014 - 2015 at Chris Hani Baragwanath Hospital alone. ${ }^{[6]]}$ In Eastern Cape Province, 5 cases were diagnosed in private sector hospitals between 2008 and 2013, but none in public sector hospitals. ${ }^{[67]}$ Assuming that the ratio of public to private sector cases in the Eastern Cape is the same as in the Western Cape $\left(10: 1^{[67]}\right)$, then an additional 45 public sector cases went undetected during this time. It is likely that many more cases are being misdiagnosed. We therefore estimated 100 cases of emergomycosis per year. Compared with emergomycosis, histoplasmosis appears to be less common in the Western Cape ${ }^{[58]}$ and more common in KwaZulu-Natal. ${ }^{[6]}$ Rarely, outbreaks associated with caving activities have been reported. ${ }^{[69,70]} \mathrm{We}$ 
Table 3. Estimated burden of fungal diseases in South Africa

\begin{tabular}{|c|c|c|c|}
\hline Mycosis & Rate, /100 000* & Cases per year, $n^{*}$ & Sensitivity bounds (lower - upper) \\
\hline Cryptococcal meningitis & 14.8 & 8357 & $6268-10446$ \\
\hline PCP & 7.9 & 4452 & $3339-5565$ \\
\hline Invasive aspergillosis & 4.8 & 3885 & $2914-4856$ \\
\hline CPA & 158.2 & 89416 & $67062-111770$ \\
\hline ABPA & 109.6 & 61938 & $46454-77423$ \\
\hline SAFS & 131.5 & 74326 & $55745-92908$ \\
\hline Candidaemia & 9.6 & 5421 & $4066-6776$ \\
\hline Peritoneal candidiasis & 3.4 & 1901 & $1426-2376$ \\
\hline Oral candidiasis & 1466 & 828666 & $621500-1035833$ \\
\hline Oesophageal candidiasis & 239 & 135289 & $101467-169111$ \\
\hline Recurrent vulvovaginal candidiasis ${ }^{\dagger}$ & 3547 & 1002499 & $751875-1253124$ \\
\hline Tinea capitis & 1775 & 1003490 & $752618-1254363$ \\
\hline Mucormycosis & 0.2 & 113 & $85-141$ \\
\hline Emergomycosis & 0.2 & 100 & $75-125$ \\
\hline Histoplasmosis & 0.1 & 60 & $45-75$ \\
\hline Sporotrichosis & 0.07 & 40 & $30-50$ \\
\hline Blastomycosis & 0.02 & 10 & $8-13$ \\
\hline Chromoblastomycosis & 0.07 & 40 & $30-50$ \\
\hline Eumycetoma & 0.02 & 10 & $8-13$ \\
\hline Total & 5.7 & 3220014 & $2415010-4025017$ \\
\hline
\end{tabular}

estimated the occurrence of 60 cases per year. While blastomycosis is endemic to SA, it is uncommon; ${ }^{[71-74]}$ we estimated 10 cases per year. Sporotrichosis, an implantation mycosis that can also present with pulmonary and disseminated disease in $\mathrm{HIV}^{[58,75]}$ has been implicated in sporadic infections and outbreaks in SA, the latter primarily reported among mineworkers. ${ }^{[59,76,77]}$ We estimated 40 cases of sporotrichosis per year. We respectively estimated 40 cases and 10 cases annually of chromoblastomycosis and eumycetoma, two other implantation mycoses.

A single study of infectious keratitis in Mopani District found 1 of $46(2.2 \%)$ cases to be fungal in aetiology using the less sensitive technique of corneal swabs; a country estimate of fungal keratitis caseload is not possible from these scanty data. ${ }^{[78]}$

\section{Discussion}

SA faces a number of important healthcare challenges, most notably HIV and associated infections including TB, but also antimicrobialresistant bacterial infections, food-borne outbreaks and noncommunicable diseases. Understanding the magnitude of respective problems will be critical for prioritising limited resources, but few national data are available to quantify the burden of fungal diseases in SA. The current study represents an attempt to estimate the burden of these infections, and adds to a growing number of national estimates demonstrating the substantial impact of mycoses. ${ }^{[4]}$ We estimated an annual burden of $\sim 3.2$ million cases of fungal diseases in SA (excluding dermatophytes other than tinea capitis), suggesting that these infections cause significant morbidity in this country.

The most frequently encountered diseases, tinea capitis and recurrent vulvovaginal candidiasis, while not life-threatening, are stigmatising and potentially debilitating for those affected. Our estimate of just over 1 million women with recurrent vulvovaginal candidiasis differs slightly from figures reported for SA in a recent global estimate only because of differences in the source data for population estimates; underlying assumptions about the prevalence of recurrent vulvovaginitis on which the estimates were made are similar. ${ }^{[79]}$ We were unable to quantify the incidence of fungal keratitis, a sight-threatening disease.

Some of the fungal diseases discussed here can be difficult to diagnose and are associated with high case-fatality rates. Cryptococcal meningitis is the leading cause of HIV-associated meningitis in southern Africa, ${ }^{[00-82]}$ and a leading cause of death among PLWH. We estimated the occurrence of 8357 cases of cryptococcal meningitis per year in SA. GERMS-SA identified 6964 cases of laboratoryconfirmed cryptococcosis (excluding cryptococcal antigenaemia), ${ }^{[14]}$ and we inflated this figure by $20 \%$ to account for additional cases that we presume have occurred in patients not receiving care or in whom the diagnosis was missed. This figure is considerably lower than that proposed by Rajasingham et al. ${ }^{[83]}$ who estimated the occurrence of 21400 cases of HIV-associated cryptococcal meningitis annually in SA. Our estimate may have been conservative, but it is based on the assumptions that untreated cryptococcal meningitis is uniformly fatal, that few individuals would die at home without presenting to hospital, and that only few patients with the disease who present in extremis would not be appropriately investigated by lumbar puncture. The case fatality rate of a first episode of cryptococcal disease in SA patients was reported to be $37 \% .{ }^{[14]}$ Fortunately, roll-out of serum cryptococcal antigen testing among persons with advanced HIV, led by the National Institute for Communicable Diseases (NICD), has enabled the detection and treatment of subclinical disease prior to progression to cryptococcal meningitis. A national programme implementing reflexive serum cryptococcal antigen screening of all HIV-seropositive patients with a CD $4+$ count $<100$ cells/ $\mu \mathrm{L}$ achieved 95\% coverage (276 125 patients) in the first year, with cryptococcal antigenaemia detected in 15757 patients (5.7\%). ${ }^{[84]}$ 
The majority of studies that have described the incidence of PCP in sub-Saharan Africa have focused on specific populations of ill patients, ${ }^{[85]}$ making determination of the true incidence challenging. We estimated 4452 cases of PCP per year, including 1691 cases in adults and 2761 in children. Our estimate of the burden of PCP in children required an estimate of the proportion of childhood pneumonias caused by PCP; the most relevant study that we could find was from Botswana prior to the widespread use of ART, ${ }^{[17]}$ and this may have led to an overestimation. It should also be noted that the number of cases proven by microscopy or by molecular testing is anticipated to be considerably fewer than our estimate, given limitations in the availability and the sensitivity of microscopy diagnosis. ${ }^{[86,87]}$ For example, Chiliza et al. ${ }^{[87]}$ reported that among adult PLWH hospitalised with suspected PCP at a tertiary hospital in Cape Town, the diagnosis was confirmed in just $55 \%$.

We estimated 5421 episodes of candidaemia in adults each year. A limitation of our estimate is that it extrapolates from data reported for a single large referral hospital's ICU, which may not reflect the true incidence across the country. For comparison with available surveillance data, the NICD's TRAC-South Africa passive laboratorybased surveillance programme - which included just 11 public sector hospitals and 85 private sector hospitals - reported 2172 cases of candidaemia over a 19-month period in 2009 and 2010. ${ }^{[37]}$ However, there are at least 544 hospitals in $\mathrm{SA},{ }^{[88]}$ suggesting that our estimate is reasonable. In the TRAC-South Africa surveillance, approximately a quarter of isolates were from neonatal ICUs, ${ }^{[89]}$ and these were not incorporated into our estimates. Whereas C. albicans is the predominant Candida species involved in candidaemia in most parts of the world, ${ }^{[90]}$ C. parapsilosis is the species most commonly implicated in candidaemia in SA, and many isolates are resistant to azole antifungals. ${ }^{[37]}$ The relatively high rate of $C$. parapsilosis is symptomatic of poor infection control procedures and/or limited antimicrobial stewardship, which may be important opportunities to reduce the burden of candidaemia and invasive candidiasis. Another major public health concern is the emergence and spread of C. auris, a multidrugresistant yeast associated with nosocomial transmission, which is increasingly being encountered in SA, particularly in ICUs in private sector hospitals. ${ }^{[1,92]}$ Publication of empirical data collected through GERMS-SA is anticipated to clarify the true incidence of candidaemia in SA (N Govender, NICD, personal communication, December 2018).

We estimated 3885 cases of IA complicating immunocompromising conditions or lung disease based on adjusted data extrapolated from resource-rich settings. In practice, few cases of IA are diagnosed in SA. The diagnosis of IA can be difficult, and usually relies on bronchoscopy for culture and/or galactomannan; the latter can also be used on serum. In SA, galactomannan testing is not widely available. Moreover, access to bronchoscopy is frequently limited to tertiary hospitals. Some international reports have found high rates of IA on autopsy of patients dying of HIV; for example, in Italy, Antinori et al. ${ }^{[24]}$ diagnosed aspergillosis on $4 \%$ of postmortem examinations of such patients. However, autopsy studies of HIV-infected patients from SA have not reported this finding. ${ }^{[25-29]}$

The high number of cases of CPA in SA reflects the high burden of $\mathrm{TB}$, and clearly requires validation. Unfortunately, the key laboratory diagnostic test (Aspergillus IgG antibody) ${ }^{[93]}$ is not available in the country, despite its first being described in the 1960s and the development of multiple commercial assays since then. ${ }^{[94,95]}$ With a $50-80 \% 5$-year mortality, this diagnostic gap is important to address nationally.

ABPA and SAFS, collectively known as 'fungal asthma', are also relatively common: asthma in adults has been measured at $6 \%{ }^{[10]}$
The estimate of ABPA is based on SA data from 1980 in a referral population of asthmatics. ${ }^{[34]}$ Referral patterns could affect this figure, and there may have been changes over the intervening 38 years. Fungal sensitisation studies are rare in Africa, and in SA limited to sensitivity of infants to Alternaria spp., ${ }^{[96]}$ limiting the reliability of our estimate of the burden of SAFS. Clearly, with $>100000$ adults affected (and an unknown number of children), fungal asthma needs to be addressed in SA as it is amenable to antifungal therapy as well as the usual treatments for asthma. ${ }^{[36]}$

HIV-associated endemic fungal infections such as emergomycosis, histoplasmosis and sometimes sporotrichosis are frequently misdiagnosed, and diagnostic delays are commonly fatal. ${ }^{[5,67]}$ Blastomycosis, which is not typically associated with HIV, is frequently characterised by a protracted course and is commonly misdiagnosed especially as TB; deaths have been infrequently reported. ${ }^{[63]}$ These and other fungal diseases are not notifiable in $\mathrm{SA},{ }^{[97]}$ so the true incidences are unclear.

Similar attempts have been made to estimate the burden of fungal disease for other countries in sub-Saharan Africa ${ }^{[98-101]}$ and elsewhere. ${ }^{[4]}$ Compared with other countries, SA has high burdens of HIV-associated and TB-associated fungal infections, reflecting the disproportionate size of these dual public health scourges. The proportion of patients affected by CPA is probably the largest in the world at 175.8/100 000. In comparison, TB-associated CPA rates were estimated for both Nigeria and the Democratic Republic of the Congo as 42.9/100 000 in 2011, , $^{[32]}$ and more recently for India as 24/100 000. ${ }^{[102]}$ Rajasingham et al. ${ }^{[83]}$ estimated the incidence of cryptococcal meningitis across countries with a uniform methodology, and found the largest burden in SA, reflecting the scale of HIV in this country. ${ }^{[83]}$

Our objective is for the estimates presented here to fill knowledge gaps regarding the burden of fungal disease in SA, pending the availability of empirical data. Robust epidemiological studies with optimal diagnostics are required to clarify the true incidence and prevalence of fungal infections. Importantly, the NICD is currently conducting critical surveillance for some of these infections (including candidaemia and cryptococcal meningitis through GERMS-SA), which will be important for supporting or supplanting some of our estimates. Additionally, careful repeated data collection over years will be important to establish trends, which we have not attempted here.

Many improvements in diagnostics could transform both the quality of current epidemiological data on fungal diseases in SA and patient care. The absence (or near absence) of Aspergillus antigen (galactomannan), Aspergillus IgG, Aspergillus IgE, and Histoplasma antigen and antibody testing are the most important gaps. Even direct microscopy for fungi is not available in most hospitals. The quiet revolution and incremental improvements in fungal disease diagnostics over the past two decades have almost bypassed SA, with the one important exception of cryptococcal antigen testing in HIV patients, in which SA is leading the world in terms of screening and case finding. Fortunately, most of the newest and best fungal diagnostic tests are inexpensive $(<\mathrm{USD} 10)$, and given their critical importance to high-quality care, they should be implemented across the country. In addition, access to effective therapy remains a challenge for many patients. Perhaps foremost among the medications to which access is urgently needed is flucytosine, an over-50-year-old medicine shown to reduce mortality from cryptococcal meningitis compared with alternatives, but which remains inaccessible in SA. ${ }^{[103,104]}$

\section{Conclusions}

Fungal infections cause a high burden of disease in SA and should be considered an important public health concern. The majority of 
these diseases are complications of HIV, TB, and/or poverty. While public health investment in the underlying conditions is essential, improving strategies for the prevention, diagnosis and management of fungal diseases can help address the morbidity and mortality associated with these conditions. ${ }^{[105]}$

\section{Declaration. None.}

Acknowledgements. None.

Author contributions. Study conception: ISS and DWD; data collection and synthesis: ISS and DWD; analysis: ISS, DWD and THB; writing of the manuscript: ISS and DWD; critical review and revision of the manuscript: ISS, DWD, THB, CRK, JCH and GDB.

Funding. Publication fees were paid via funding from a grant from Fonds Wetenschappelijk Onderzoek - Vlaanderen to CRK.

Conflicts of interest. None.

1. Joint United Nations Programme on HIV and AIDS (UNAIDS). Global AIDS Update 2016. Geneva UNAIDS, 2016. https://www.unaids.org/sites/default/files/media_asset/global-AIDS-update-2016 en.pdf (accessed April 14 2018)

2. World Health Organization. Global Tuberculosis Report 2017. Geneva: WHO, 2017. https://www.who. int/tb/publications/global_report/gtbr2017_main_text.pdf (accessed 14 April 2018).

3. Sulla V, Zikhali P. Overcoming Poverty and Inequality in South Africa : An Assessment of Drivers, Constraints and Opportunities. Washington, DC: World Bank Group, 2018. http://documents. worldbank.org/curated/en/530481521735906534/Overcoming-Poverty-and-Inequality-in-Southworldbank.org/curated/en/530481521735906534/Overcoming-Poverty-and-Inequality-in-So
Africa-An-Assessment-of-Drivers-Constraints-and-Opportunities (accessed 10 December 2018).

4. Global Action Fund for Fungal Infections (Gaffi). Publications. https://www.gaffiorg/media/ Global Action Fund for Fungal Infections (Gaffi). Publications.
academic-papers/\#countryburdens (accessed 17 September 2019).

5. Statistics South Africa. Mid-year population estimates 2018. 2018. Statistical release P0302. Pretoria: . Statistics South Africa. Mid-year population estimates 2018. 2018. Statistical release P0302. Pretoria:
Stats SA, 2018. https://www.statssa.gov.za/publications/P0302/P03022018.pdf (accessed 27 July 2018)

6. Johnson LF, Dorrington RE, Moolla H. Progress towards the 2020 targets for HIV diagnosis and antiretroviral treatment in South Africa. South Afr J HIV Med 2017;18(1):1-8. https://doi.org/10.4102/ sajhivmed.v18i1.694

. Carmona S, Bor J, Nattey C, et al. Persistent high burden of advanced HIV disease among patients seeking care in South Africass national HIV program: Data from a nationwide laboratory cohort. Clin Infect Dis 2018;66(Suppl 2):S111-S117. https://doi.org/10.1093/cid/ciy045

8. Coetzee LM, Cassim N, Glencross DK. Analysis of HIV disease burden by calculating the percentages of patients with CD4 counts $<100$ cells/ $\mu \mathrm{L}$ across 52 districts reveals hot spots for intensified commitment to programmatic support. S Afr Med J 2017;107(6):507-513. https://doi.org/10.7196/ SAMJ.2017.v107i6.11311

9. Institute for Health Metrics and Evaluation. GBD Compare | IHME Viz Hub. 2017. https://vizhub. healthdata.org/gbd-compare/\# (accessed 14 April 2018).

10. To T, Stanojevic S, Moores G, et al. Global asthma prevalence in adults: Findings from the crossTo T, Stanojevic S, Moores G, et al. Global asthma prevalence in adults: Findings from the cross-
sectional World Health Survey. BMC Public Health 2012;12(1):204. https://doi.org/10.1186/14712458-12-204

11. Organ Donor Foundation. Statistics: Organ Donor Foundation; 2019. https://www.odf.org.za/infoand-faq-s/statistics.html (accessed 17 September 2019).

12. Passweg JR, Baldomero H, Bader P, et al. Hematopoietic stem cell transplantation in Europe 2014: More than 40000 transplants annually. Bone Marrow Transplant 2016;51(6):786-792. https://doi. org/10.1038/bmt.2016.20

13. Davids MR, Marais N, Jacobs JC. South African Renal Registry Annual Report 2015. Afr J Nephrol 2017;20(1):201-213. https://doi.org/10.21804/20-1-2583

14. National Institute for Communicable Diseases. GERMS-SA Annual Report 2016. Johannesburg: NICD, 2017. http://www.nicd.ac.za/wp-content/uploads/2017/03/GERMS-SA-AR-2016-FINAL.pdf (accessed 12 December 2018).

15. Meyer-Rath G, Brennan AT, Fox MP, et al. Rates and cost of hospitalization before and after initiation of antiretroviral therapy in urban and rural settings in South Africa. J Acquir Immune Defic Syndr 2013;62(3):322-328. https://doi.org/10.1097/QAI.0b013e31827e8785

16. Maartens G, Stewart A, Griesel R, et al. Development of a clinical prediction rule to diagnose Pneumocystis jirovecii pneumonia in the World Health Organization's algorithm for seriously ill HIVPneumocystis jiroveci pneumonia in the World Health Organization's algorithm for seriously ill HIV
infected patients. South Afr J HIV Med 2018;19(1):a851. https://doi.org/10.4102/sajhivmed.v19i1.851

infected patients. South Afr J HIV Med 2018;19(1):a851. https://doi.org/10.4102/sajhivmed.v19i1.851
17. Ansari NA, Kombe AH, Kenyon TA, et al. Pathology and causes of death in a series of human immunodeficiency virus-positive and -negative pediatric referral hospital admissions in Botswana Pediatr Infect Dis J 2003;22(1):43-47. https://doi.org/10.1097/00006454-200301000-00013

18. Zar HJ, Hanslo D, Tannenbaum E, et al. Aetiology and outcome of pneumonia in human immunodeficiency virus-infected children hospitalized in South Africa. Acta Paediatr 2001;90(2):119125. https://doi.org/10.1111/j.1651-2227.2001.tb00270.x

19. Morrow BM, Samuel CM, Zampoli M, Whitelaw A, Zar HJ. Pneumocystis pneumonia in South African children diagnosed by molecular methods. BMC Res Notes 2014;7:26. https://doi.org/10.1186/17560500-7-26

20. Lortholary O, Gangneux JP, Sitbon K, et al. Epidemiological trends in invasive aspergillosis in France: The SAIF network (2005 - 2007). Clin Microbiol Infect 2011;17(12):1882-1889. https://doi. org/10.1111/j.1469-0691.2011.03548.x

21. Herbrecht R, Bories P, Moulin J-C, Ledoux M-P, Letscher-Bru V. Risk stratification for invasive aspergillosis in immunocompromised patients. Ann N Y Acad Sci 2012;1272(1):23-30. https://doi. org/10.1111/j.1749-6632.2012.06829

22. Yan X, Li M, Jiang M, Zou L-q, Luo F, Jiang Y. Clinical characteristics of 45 patients with invasive pulmonary aspergillosis. Cancer 2009;115(21):5018-5025. https://doi.org/10.1002/cncr.24559

23. Guinea J, Torres-Narbona M, Gijón P, et al. Pulmonary aspergillosis in patients with chronic obstructive pulmonary disease: Incidence, risk factors, and outcome. Clin Microbiol Infect 2010;16(7):870-877. https://doi.org/10.1111/j.1469-0691.2009.03015.x

24. Antinori S, Nebuloni M, Magni C, et al. Trends in the postmortem diagnosis of opportunistic invasive fungal infections in patients with AIDS: A retrospective study of 1,630 autopsies performed between 1984 and 2002. Am J Clin Pathol 2009;132(2):221-227. https://doi.org/10.1309/AJCPRAAE8LZ7DTNE

25. Karat AS, Omar T, von Gottberg A, et al. Autopsy prevalence of tuberculosis and other potentially treatable infections among adults with advanced HIV enrolled in out-patient care in South Africa. PLoS One 2016;11(11):e0166158. https://doi.org/10.1371/journal.pone.0166158
26. Martinson NA, Karstaedt A, Venter WD, et al. Causes of death in hospitalized adults with a premortem diagnosis of tuberculosis: An autopsy study. AIDS 2007;21(15):2043-2050. https://doi.org/10.1097/ QAD.0b013e3282eea47

27. Wong EB, Omar T, Sethako GJ, et al. Causes of death on antiretroviral therapy: A post-mortem study from South Africa. PLoS One 2012;7(10)::47542. https://doi.org/10.1371/journal.pone. 0047542

28. Murray J, Sonnenberg P, Nelson G, Bester A, Shearer S, Glynn JR. Cause of death and presence of respiratory disease at autopsy in an HIV-1 seroconversion cohort of southern African gold miners. AIDS 2007;21(Suppl 6):S97-S104. https://doi.org/10.1097/01.aids.0000299416.61808.24

29. Garcia-Jardon M, Bhat VG, Blanco-Blanco E, Stepian A. Postmortem findings in HIV/AIDS patients in a tertiary care hospital in rural South Africa. Trop Doct 2010;40(2):81-84. https://doi.org/10.1258 td. 2010.090465

30. Torres-Narbona M, Guinea J, Martínez-Alarcón J, et al. Impact of zygomycosis on microbiology workload: A survey study in Spain. J Clin Microbiol 2007;45(6):2051-2053. https://doi.org/10.1128/ JCM.02473-06

31. Bitar D, van Cauteren D, Lanternier F, et al. Increasing incidence of zygomycosis (mucormycosis), France, 1997 - 2006. Emerg Infect Dis 2009;15(9): 1395-1401. https://doi.org/10.3201/eid1509.090334

32. Denning DW, Pleuvry A, Cole DC. Global burden of chronic pulmonary aspergillosis as a sequel to Denning DW, Pleuvry A, Cole DC. Global burden of chronic pulmonary aspergillosis as a sequel to
pulmonary tuberculosis. Bull World Health Organ 2011;89(12):864-872. https://doi.org/10.2471/ pulmonary tuber.

33. Sonnenberg P, Murray J, Glynn JR, Thomas RG, Godfrey-Faussett P, Shearer S. Risk factors for pulmonary disease due to culture-positive M. tuberculosis or nontuberculous mycobacteria in South African gold miners. Eur Respir J 2000;15(2):291-296. https://doi.org/10.1034/j.1399-3003.2000.15b12.x

34. Benatar SR, Keen GA, Naude WDT. Aspergillus hypersensitivity in asthmatics in Cape Town. Clin Exp Allergy 1980;10(3):285-291. https://doi.org/10.1111/j.1365-2222.1980.tb02109.x

35. Denning DW, Pleuvry A, Cole DC. Global burden of allergic bronchopulmonary aspergillosis with asthma and its complication chronic pulmonary aspergillosis in adults. Med Mycol 2013;51(4):361-370. https://doi.org/10.3109/13693786.2012.738312

36. Denning DW, Pashley C, Hartl D, et al. Fungal allergy in asthma - state of the art and research needs. Clin Transl Allergy 2014;4(1):14. https://doi.org/10.1186/2045-7022-4-14 37. Govender NP, Patel J, Magobo RE, et al. Emergence of azole-resistant Candida parapsilosis causing
bloodstream infection: Results from laboratory-based sentinel surveillance in South Africa. J Antimicrob bloodstream infection: Results from laboratory-based sentinel surveillance
Chemother 2016;71(7):1994-2004. https://doi.org/10.1093/jac/dkw091

38. Naidoo K, Singh J, Lalloo U. Critical analysis of ICU/HC beds in South Africa: 2008 - 2009. S Afr Med J 2013;103(10):751-753. https://doi.org/10.7196/SAMJ.6415

39. Kreusch A, Karstaedt AS. Candidemia among adults in Soweto, South Africa, 1990 - 2007. Int J Infect Dis 2013;17(8):e621-e623. https://doi.org/10.1016/ji.ijid.2013.02.010

40. Tshukutsoane S, Scribante J. This is my unit: Chris Hani Baragwanath ICU, Soweto, South Africa Connect: The World of Critical Care Nursing 2008;6(1):10-12. http://doi.org/10.1891/1748-6254.6.1.10

41. Montravers P, Mira J-P, Gangneux J-P, Leroy O, Lortholary O. A multicenter study of antifungal strategies and outcome of Candida spp. peritonitis in intensive care units. Clin Microbiol Infect 2011;17(7):10611067. https://doi.org/10.1111/j.1469-0691.2010.03360.x

42. Okpechi IG, Rayner BL, Swanepoel CR. Peritoneal dialysis in Cape Town, South Africa. Perit Dial Int 2012;32(3):254-260. https://doi.org/10.3747/pdi.2011.00100

43. Isla RAT, Mapiye D, Swanepoel CR, Rozumyk N, Hubahib JE, Okpechi IG. Continuous ambulatory peritoneal dialysis in Limpopo Province, South Africa: Predictors of patient and technique survival. Perit Dial Int 2014;34(5):518-525. https://doi.org/10.3747/pdi.2013.00334

44. Arendorf TM, Bredekamp B, Cloete CA, Sauer G. Oral manifestations of HIV infection in 600 South African patients. J Oral Pathol Med 1998;27(4):176-179. https//doi.org/10.1111/j.1600-0714.1998. tb01936.x

45. Nanteza M, Tusime JB, Kalyango J, Kasangaki A. Association between oral candidiasis and low CD4+ count among HIV positive patients in Hoima Regional Referral Hospital. BMC Oral Health 2014;14:143. https://doi.org/10.1186/1472-6831-14-143

46. Meless D, Ba B, Faye M, et al. Oral lesions among HIV-infected children on antiretroviral treatment in West Africa. Trop Med Int Health 2014;19(3):246-255. https://doi.org/10.1111/tmi.12253

47. Arrive E, Meless D, Anaya-Saavedra G, Gallottini M, Pinzon LM, Ramirez-Amador V. The global burden of oral diseases in pediatric HIV-infected populations: A workshop report. Oral Dis 2016:22(Suppl 1):149157. https://doi.org/10.1111/odi.12417

48. Rwenyonyi CM, Kutesa A, Muwazi L, Okullo I, Kasangaki A, Kekitinwa A. Oral manifestations in HIV/ Rwenyonyi CM, Kutesa A, Muwazi L, Okullo I, Kasang
AIDS-infected children. Eur J Dent 2011;5(3):291-298.

49. Smith E, Orholm M. Trends and patterns of opportunistic diseases in Danish AIDS patients 1980 - 1990 Scand J Infect Dis 1990;22(6):665-672. https://doi.org/10.3109/00365549009027119

50. Ramjee G, Karim SSA, Sturm AW. Sexually transmitted infections among sex workers in KwaZulu-Natal, South Africa. Sex Transm Dis 1998;25(7):346-349. https://doi.org/10.1097/00007435-199808000-00004

51. Apalata T, Carr WH, Sturm WA, Longo-Mbenza B, Moodley P. Determinants of symptomatic vulvovagina candidiasis among human immunodeficiency virus type 1 infected women in rural KwaZulu-Natal, South Africa. Infect Dis Obstet Gynecol 2014;2014:1-10. https://doi.org/10.1155/2014/387070

52. Sobel JD. Vulvovaginal candidosis. Lancet 2007;369(9577):1961-1971. https://doi.org/10.1016/S01406736(07)60917-9

53. Foxman B, Muraglia R, Dietz JP, Sobel JD, Wagner J. Prevalence of recurrent vulvovaginal candidiasis in 5 European countries and the United States: Results from an internet panel survey. J Low Genit Tract Dis 2013;17(3):340-345. https:// doi.org/10.1097/LGT.0b013e318273e8cf

54. Nweze EI, Eke IE. Dermatophytes and dermatophytosis in the eastern and southern parts of Africa. Med Mycol 2017;November:1-17. https://doi.org/10.1093/mmy/myx025

55. Young CN. Scalp ringworm among black children in South Africa and the occurrence of Trichophyton . Young CN. Scalp ringworm among black ch
yaoundei. S Afr Med J 1976;50(18):705-707.

yaoundei. S Afr Med J 1976;50(18):705-707.
56. John AM, Schwartz RA, Janniger CK. The kerion: An angry tinea capitis. Int J Dermatol 2018;57(1):3-9. 6. John AM, Schwartz RA, Janniger
https://doi.org/10.1111/ijd.13423

7. Zaraa I, Hawilo A, Aounallah A, et al. Inflammatory tinea capitis: A 12-year study and a review of the literature. Mycoses 2013;56(2):110-116. https://doi.org/10.1111/j.1439-0507.2012.02219.x

58. Schwartz IS, Kenyon C, Lehloenya R, et al. AIDS-related endemic mycoses in Western Cape, South Africa, and clinical mimics: A cross-sectional study of adults with advanced HIV and recent-onset, widespread skin lesions. Open Forum Infect Dis 2017;4(4):ofx 186. https://doi.org/10.1093/ofid/ofx186

59. Govender NP, Maphanga TG, Zulu TG, et al. An outbreak of lymphocutaneous sporotrichosis among mine-workers in South Africa. PLoS Negl Trop Dis 2015;9(9):e0004096. https://doi.org/10.1371/journal pntd. 0004096

60. Simson FW. Chromoblastomycosis: Some observations on the types of the disease in South Africa Mycologia 1946;38(4):432-449.

61. Bayles MA. Tropical mycoses. Chemotherapy 1992;38(Suppl 1):27-34. https://doi.org/10.1159/000239050 62. Bayles MA. Chromomycosis. Curr Top Med Mycol 1995;6:221-243.

63. Frean JA, Carman WF, Crewe-Brown HH, Culligan GA, Young CN. Blastomyces dermatitidis infections in the RSA. S Afr Med J 1989;76(1):13-16.

64. Coovadia H, Jewkes R, Barron P, et al. The health and health system of South Africa: Historical roots of current public health challenges. Lancet 2009;374(9692):817-834. https://doi.org/10.1016/S01406736(09)60951-X

65. Maphanga TG, Britz E, Zulu TG, et al. In vitro antifungal susceptibility of yeast and mold phases of infected South Afric fungal pathogen Emergomyces africanus (formerly Enmc 
66. Bhagoobhai L, Seetharam S, Wadula J. Dimorphic fungus (Emmonsia species) isolated from sterile sites between March 2014 to April 2015. Presented at the 6th FIDSSA Congress, Drakensberg, KwaZuluNatal, South Africa, 5 - 7 November 2015

67. Schwartz IS, Govender NP, Corcoran C, et al. Clinical characteristics, diagnosis, management and outcomes of disseminated emmonsiosis: A retrospective case series. Clin Infect Dis 2015;61(6):10041012. https://doi.org/10.1093/cid/civ439

68. Ramdial PK, Mosam A, Dlova NC, Satar NB, Aboobaker J, Singh SM. Disseminated cutaneou histoplasmosis in patients infected with human immunodeficiency virus. J Cutan Patho 2002;29(4):215-225. https://doi.org/10.1034/j.1600-0560.2002.290404.x

69. Craven SA, Benatar SR. Histoplasmosis in the Cape Province: A report of the second known outbreak S Afr Med J 1979;55(3):89-92.

70. Craven SA. Histoplasmosis - a possible outbreak in the northern Cape Province. S Afr Med 1981;60(4):125.

71. Frean JA, Carman WF, Crewe-Brown HH, Culligan GA, Young CN. Blastomyces dermatitidis infections in the RSA. S Afr Med J 1989;76(1):13-16.

72. Carman WF Frean JA, Crewe-Brown HH, Culligan GA, Young CN. Blastomycosis in Africa: A review of known cases diagnosed between 1951 and 1987. Mycopathologia 1989;107(1):25-32. https://doi org $/ 10.1007 / \mathrm{bf} 00437587$

73. Frean J, Blumberg L, Woolf M. Disseminated blastomycosis masquerading as tuberculosis. J Infect 1993;26(2):203-206. https://doi.org/10.1016/0163-4453(93)93031-

74. Motswaledi HM, Monyemangene FM, Maloba BR, Nemutavhanani DL. Blastomycosis: A case report and review of the literature. Int J Dermatol 2012;51(9):1090-1093. https://doi.org/10.1111/j.13654632.2011.05369.x

75. Bonifaz A, Tirado-Sánchez A. Cutaneous disseminated and extracutaneous sporotrichosis: Current status of a complex disease. J Fungi (Basel) 2017;3(1):6. https://doi.org/10.3390/jof3010006

76. Helm MAF, Berman C. The clinical, therapeutic and epidemiological features of sporotrichosis infection on the mines. In: Sporotrichosis Infection on Mines of the Witwatersrand. Johannesburg: infection on the mines. In: Sporotrichos.

77. Quintal D. Sporotrichosis infection on mines of the Witwatersrand. J Cutan Med Surg 2000;4(1):51-54. https://doi.org/10.1177/120347540000400113

78. Schaftenaar E, Peters RPH, Baarsma GS, et al. Clinical and corneal microbial profile of infectious keratitis in a high HIV prevalence setting in rural South Africa. Eur J Clin Microbiol Infect Dis 2016;35(9):1403-1409. https://doi.org/10.1007/s10096-016-2677-x

79. Denning DW, Kneale M, Sobel JD, Rautemaa-Richardson R. Global burden of recurrent vulvovaginal candidiasis: A systematic review. Lancet Infect Dis 2018;18(11):PE339-E347. https://doi.org/10.1016/ S1473-3099(18)30103-8

80. Britz E, Perovic O, von Mollendorf C, et al. The epidemiology of meningitis among adults in a South African province with a high HIV prevalence, 2009 - 2012 PLoS One 2016;11(9):e0163036 https.//dol. org $/ 10.1371 /$ journal pone 0163036

81. Jarvis IN, Meinties G, Williams A, Brown Y, Crede T, Harrison TS. Adult meningitis in a setting of high HIV and TB prevalence: Findings from 4961 suspected cases. BMC Infect Dis 2010;10:67. https://doi. HIV and TB prevalence: Fin

82. Veltman JA, Bristow CC, Klausner JD. Meningitis in HIV-positive patients in sub-Saharan Africa: A review. J Int AIDS Soc 2014;17:19184. https://doi.org/10.7448/IAS.17.1.19184

83. Rajasingham R, Smith RM, Park BJ, et al. Global burden of disease of HIV-associated cryptococcal meningitis: An updated analysis. Lancet Infect Dis 2017;17(8):873-881. https://doi.org/10.1016/S1473 3099(17)30243-8

84. Govender NP, Glencross DK. National coverage of reflex cryptococcal antigen screening: A milestone achievement in the care of persons with advanced HIV disease. S Afr Med J 2018:108(7):534-535 https://doi.org/10.7196/SAMJ.2018.v108i7.13094

85. Wasserman S, Engel ME, Griesel R, Mendelson M. Burden of pneumocystis pneumonia in HIV infected adults in sub-Saharan Africa: A systematic review and meta-analysis. BMC Infect Dis 2016;16:482. https://doi.org/10.1186/s12879-016-1809-3
86. Oladele RO, Otu AA, Richardson MD, Denning DW. Diagnosis and management of Pneumocystis pneumonia in resource-poor settings. J Health Care Poor Underserved 2018;29(1):107-158. https:// doi.org/10.1353/hpu.2018.0010

87. Chiliza N, du Toit M, Wasserman S. Outcomes of HIV-associated pneumocystis pneumonia at a South African referral hospital. PLoS One 2018;13(8):e0201733. https://doi.org/10.1371/journal. pone. 0201733

88. Dell AJ, Kahn D. Geographical maldistribution of surgical resources in South Africa: A review of the number of hospitals, hospital beds and surgical beds. S Afr Med J 2017;107(12):1099-1105. https://doi. org/10.7196/SAMJ.2017.v107i12.12539

89. Magobo RE, Naicker SD, Wadula J, et al. Detection of neonatal unit clusters of Candida parapsilosis ungaemia by microsatellite genotyping: Results from laboratory-based sentinel surveillance, South Africa, 2009 - 2010. Mycoses 2017;60(5):320-327. https://doi.org/10.1111/myc.12596

90. Lamoth F, Lockhart SR, Berkow EL, Calandra T. Changes in the epidemiological landscape of invasive candidiasis. J Antimicrob Chemother 2018;73(Suppl 1):i4-i13. https://doi.org/10.1093/jac/dkx444

91. Lockhart SR, Etienne KA, Vallabhaneni S, et al. Simultaneous emergence of multidrug-resistant Candida auris on 3 continents confirmed by whole-genome sequencing and epidemiological analyses. Clin Infect Dis 2017;64(2):134-140. https://doi.org/10.1093/cid/ciw691

92. Govender NP, Magobo RE, Mpembe R, et al. Candida auris in South Africa, 2012 - 2016. Emerg Infect Dis 2018;24(11). https://doi.org/10.3201/eid2411.180368

93. Denning DW, Page ID, Chakaya J, et al. Case definition of chronic pulmonary aspergillosis in resourceconstrained settings. Emerg Infect Dis 2018;24(8). https://doi.org/10.3201/eid2408.171312

94. Page ID, Richardson M, Denning DW. Antibody testing in aspergillosis - quo vadis? Med Mycol 2015;53(5):417-439. https://doi.org/10.1093/mmy/myv02

95. Dumollard C, Bailly S, Perriot S, et al. Prospective evaluation of a new aspergillus IgG enzyme mmunoassay kit for diagnosis of chronic and allergic pulmonary aspergillosis. J Clin Microbiol 2016;54(5):1236-1242. https://doi.org/10.1128/JCM.03261-15

96. De Benedictis FM, Franceschini F, Hill D, et al. The allergic sensitization in infants with atopic eczema from different countries. Allergy 2009;64(2):295-303. https://doi.org/10.1111/j.13989995.2008.01779.x

97. National Institute of Communicable Diseases. Notifiable medical conditions. http://www.nicd.ac.za/ notifiable-medical-conditions/ (accessed 17 September 2019).

98. Parkes-Ratanshi R, Achan B, Kwizera R, Kambugu A, Meya D, Denning DW. Cryptococcal disease and the burden of other fungal diseases in Uganda: Where are the knowledge gaps and how can we fill them? Mycoses 2015;58(Suppl 5):85-93. https://doi.org/10.1111/myc.12387

99. Oladele RO, Denning DW. Burden of serious fungal infection in Nigeria. West Afr J Med 2014;33(2):107-114.

100. Faini D, Maokola W, Furrer H, et al. Burden of serious fungal infections in Tanzania. Mycoses 2015;58(Suppl 5):70-79. https://doi.org/10.1111/myc.12390

01. Guto JA, Bii CC, Denning DW. Estimated burden of fungal infections in Kenya. J Infect Dev Ctries 2016;10(8):777-784. https://doi.org/10.3855/jidc.7614

102. Agarwal R, Denning DW, Chakrabarti A. Estimation of the burden of chronic and allergic pulmonary aspergillosis in India. PLoS One 2014;9(12):e1 14745. https://doi.org/10.1371/journal.pone.0114745

3. Govender NP, Meinties G, Banoo S. Access to flucytosine for HIV-infected patients with cryptococcal meningitis - an urgent need. S Afr Med J 2014;104(9):594-595. https://doi.org/10.7196/SAMJ.8713

104. Day JN, Chau TTH, Wolbers M, et al. Combination antifungal therapy for cryptococcal meningitis. N Engl J Med 2013;368(14):1291-1302. https://doi.org/10.1056/NEJMoa1110404

105. Denning DW. Minimizing fungal disease deaths will allow the UNAIDS target of reducing annual AIDS deaths below 500000 by 2020 to be realized. Philos Trans R Soc Lond B Biol Sci 2016:371(1709). https://doi.org/10.1098/rstb.2015.0468

Accepted 26 April 2019. 